ceived as a complex assemblage of chemical reactions, each subject to the same laws. "One of the sources of the richness and subtlety shown by the behaviour of living matter," he wrote, "is the way in which, in the individual, physico-chemical laws can play variations on the fundamental theme expressed by the genetic code, while populations can also respond in another way to rarer and more catastrophic changes in the code itself." $\mathrm{He}$ discussed these laws in many papers and in two books, The Chemical Kinetics of the Bacterial Cell (1946) and (with A. C. R. Dean) Growth, Function and Regulation in Bacterial Cells (1966). The question of cellular regulation was a recurring theme which found expression in what he called "the principle of total integration" and the "network theorem". These expressed in mathematical terms the mutual interdependence of all the components in the intact functioning cell. He had been asked for a non-mathematical presentation. Two days before his death, he wrote of his intention to do this, "pointing out where, which is in most places, the model is not in conflict with other descriptions, but adds something of its own". He was not unaware that his incursions into biology had encountered some scepticism among a few of the more traditional professional biologists. In his elegant book The Structure of Physical Chemistry (1951) he presented a unified, coherent story in his own eritically philosophic way. His first book, Thermodynamics for Students of Chemistry (1926), is another, less known, classic.

Hinshelwood was in turn president of the Chemical Society, Faraday Society, Royal Society, the British Association, and of the Classical Association; chairman of the Research Committee of the Gas Council, a delegate of the Clarendon Press, chairman of the Council of Queen Elizabeth College, London, a trustee of the British Museum, and on the court of the Goldsmiths Company. $\mathrm{He}$ served on many governmental advisory committees. His honours included the Davy, Royal, Copley and Leverhulme medals of the Royal Society, the Longstaff and Faraday medals of the Chemical Society, the Nobel Prize for Chemistry (shared with Semenov) and many medals given by foreign organizations. He received honorary doctorates from about a dozen universities, was a member of many foreign academies, and an honorary fellow of four Oxford colleges. In 1960 he received the Order of Merit.

To his fluency in numerous European languages there was added a competence in Russian and Chinese, with a little Arabic. He had a wide knowledge of English and foreign literature, of operatic music, of Chinese porcelain and Persian carpets, and was an accomplished painter in oils. He often contributed papers to the Oxford Dante Society. He was regarded with affection and respect by his colleagues, and by undergraduates in both the sciences and the humanities. In all his lectures and writings there was an unmistakable mark of the natural philosopher. None was more fitted than "Hinsh" to drink the tradi. tional toast of the Royal Society's dining club: "Arts and Sciences".

H. W. T.

\section{Dr Pierre Jacquet}

Pierre Jacquet and his wife died tragically at sea near Puerto de la Selva, Spain, during a trip in their cabin cruiser on September 6, 1967. Jacquet was born in 1906 at Saint-Mande (Seine), graduated as a chemical engineer from the Institut de Chimie, Paris, in 1926, and obtained his doctorate in 1938. He was well known throughout the world as the father of electropolishing, a phenomenon which he discovered in association with $\mathrm{H}$. Figour in 1929.

$\mathrm{He}$ first described this process in the Comptes Rendus in $1935(201,1473)$, and spent the rest of his scientific life investigating fundamental aspects of the phenomenon, applying it to a wide range of metals and alloys, and encouraging its industrial application. This work is recorded in more than 200 papers published in manyjournals in France and elsewhere. It is no exaggeration to say that electrolytic polishing has revolutionized not only the practice of metallography by providing the most scientific way of preparing polished surfaces free from strain and blemishes, but also methods of surface preparation in industry where it is now extensively used for polishing and machining. In addition, the present techniques of electron microscopy of metals and alloys are almost entirely dependent on methods pioneered by Jacquet. In recent years Jacquet developed the technique further so that it could be used in situ on larger structures or objects, thus initiating a new approach in non-destruc. tive metallography. A detailed list of the fields in which Jacquet has made effective contributions would include most of the important aspects of physical metallurgy. Much of his early work was done in the Research Labor. atory of the Société, le Materiel Téléphonique, but since 1945 he worked in the Research Laboratory of the French Navy, from which he had only recently retired.

His scientific work has been recognized by many awards including the Berthelot Medal (1956), the Jaffe Prize of the French Academy, and the Le Chatelier Medal of the Société Française de Métallurgie. He was a Chevalier de la Légion d'Honneur and an Honorary Foreign Member of the American Academy of Arts and Seiences (1956).

Jaequet will be long remembered as a modest, retiring man who by firm conviction and a long scientific career at the laboratory bench made outstanding contributions to metallurgical science and technology.

\section{R. W. K. Honeycombe}

\section{Dr Francis Silsbee}

Francis Briggs Silsbee, who died on August 21, aged 78, retired as Chief of the Electricity Division of the US National Bureau of Standards in 1959. He had made many contributions to electrical engineering.

Silsbee graduated in electrical engineering from the Massachusetts Institute of Technology in 1910 and obtained a master's degreo the following year. In 1915 he obtained his doctorate from Harvard University. He joined the National Bureau of Standards in 1911, and continued to act as a consultant after his retirement, when he was interested in the history of the scientific work of the bureau. He was chairman of a committee whose work led to the establishment of the NBS Museum, which exhibits instruments made during the 66 years of the bureau's existence.

Silsbee's contributions to electrical engineering included involvement in the design of alternating current resistors of exceptionally low reactance. He also invented the test set which is used by industry to compare working current transformers with standard transformers of known ratio and phase angle. During the Second World War, he investigated lighting hazards to aireraft for the National Advisory Committee of Aeronautics. As chief of the Electricity Division at the National Bureau of Standards he was concerned with ostablishing electrical units and standards, and took part in committee work with the International Electrotechnical Commission and other standardizing organizations. In 1956 Silsbee was sent to Ethiopia by the International Co-operation Commission to advise the government on the establishment of a national system of measurement standards.

Silsbee was a fellow of the Institute of Electrical and Electronics Engineers, a fellow of the American Physical Society, and a former president of the Washington Philosophical Society and the Washington Academy of Sciences. In 1963 he received the Morris E. Leeds Award for his contribution to the methods of improving the accuracy of commercial electrical measurements. He also received Exceptional Service Awards from the Department of Commerce and the Naval Bureau of Ordinance. 